\title{
Nigerian Literature: Beyond Languages and Borders
}

\author{
Barclays Foubiri Ayakoroma, $\mathbf{P h D}^{1}$ \\ ${ }^{I}$ Executive Secretary/CEO, National Institute for Cultural Orientation (NICO), Abuja-FCT, Nigeria/ Visiting \\ Associate Professor, Nasarawa State University, Keffi, Nigeria
}

*Corresponding Author: Barclays Foubiri Ayakoroma, PhD., Executive Secretary/CEO, National Institute for Cultural Orientation (NICO), Abuja-FCT, Nigeria/ Visiting Associate Professor, Nasarawa State University, Keffi, Nigeria. Email:dr.barclays@gmail.com

\begin{abstract}
Language, therefore, is critical in laying the foundation of every literary expression. But then, the extent to which a literary work is identified favourably within and outside its cultural context will go a long way in establishing it as a veritable instrument in defining identify of a people. This paper examines the present state of literary writing in Nigeria and how the various writings have gone beyond the immediate borders of the cultural environments where they were written. Incidentally, some factors militate against the seamless proliferation of such literary writings in Nigeria. The paper submits that, it could be said that there is a bright future for literary writings in Nigeria. The writings will continue to go beyond the borders of the country, telling the "Nigerian story" and the "Nigerian identity" to the outside world.
\end{abstract}

Keywords: Literature, Language, Borders.

\section{INTRODUCTION}

There are well over 250 spoken languages in Nigeria; this is outside the fact that there are about 510 dialects. Incidentally, English has become the lingua franca, apparently to enhance the cultural and linguistic unity of the country. But the truth is that English remains an exclusive preserve of the urban dwellers, as it is not widely spoken in the rural areas, where majority of the country's estimated population of about 160 million people are domiciled. The major Nigerian languages are Hausa, Igbo, Yoruba, Ijaw, Fulfulde, Tiv, Ibibio, and Urhobo. As a point of fact, the National Institute for Cultural Orientation (NICO), teaches 13 languages so far in its Nigerian Indigenous Language Programme (NILP), namely, Hausa, Igbo, Yoruba, Izon, Tiv, Efik, Urhobo, Gbagyi, Nupe, Batonu, Bwatiye, Chamba and Fulfulde. Unarguably, Nigeria's linguistic diversity is a microcosm of Africa, as a whole, encompassing three major African language families: Afro-Asiatic, Nilo-Saharan, and Niger-Congo.

The arts involve human activities, creativity and modes of expression, like drama, poetry, music, literature, film, photography, sculpture, and painting. Language, therefore, is critical in laying the foundation of every literary expression. But then, the extent to which a literary work is identified favourably within and outside its cultural context will go a long way in establishing it as a veritable instrument in defining identify of a people.

\section{LITERATURE, LANGUAGE AND BORDERS}

The word, literature, literally means, "things made from letters;" though not everything that is written down is seen as literature. It is the body of written works of a language, period, or culture; imaginative or creative writing, especially of recognized artistic value; or the body of written work produced by scholars or researchers in a given field, for example, medical literature or Christian literature. Literature could also mean printed or collected materials on a given subject. It is commonly classified as having two major forms, fiction and non-fiction; and three major genres - drama, poetry and prose.

There is general agreement that literature foregrounds language and uses it in artistic ways. In examining the relationship between literature and language, Terry Eagleton states that, "literature transforms and intensifies ordinary language, deviates systematically from everyday speech;" and that it is not definable according to whether it is fictional or imaginative but because, "it uses language in peculiar ways." 
In exploring ideas about what literature is, it is pertinent to look at some of the things that it does. Literature mirrors society; it makes us think about ourselves and our society; it allows us to enjoy language and beauty; and it reflects on the human condition and can be didactic. It reflects both ideology and changes ideology, just like it follows generic conventions, changing them. Literature is the creation of another world by a writer, a world that we can only see when we read such literary pieces.

Egya Sule, a poet and literary critic teaching at the University of Abuja, states that creative or literary writing can be defined in just one word: "metaphorisation." According to him, this entails the art of making familiar words and expressions unfamiliar, surmising that:

This is the root or basis of all creative writing. All creative writing must task our senses, must demand from us extra attention, and must mystify our daily realities. Only few people writing today understand the strategy of literary creativity (Akubuiro, NLNG Prizes has not...”).

On the other hand, language, as a component of culture, is a means of communication. It is a human and non-instructive way of communicating ideas, emotions and desires by means of voluntarily produced symbols. Language is the central feature of the culture of any community and a reflection of the thoughts, feelings, values, beliefs and the experiences of a community of speakers. In other words, it is a human and non-instinctive medium of communication acquired through social interaction in early childhood. This implies that language is not inborn and therefore must be learnt by the speakers. As a system of communication in writing, for example, the effective study and use of the language of a people is essential for their identity and all-round development, socially, politically, culturally or economically.

Language ensures certain amount of uniformity, thereby facilitating interpersonal cognitive communication, without which shared values and traditions would be impossible and the very fabric of community and national integration could be hindered. It is a veritable instrument in the sustenance of peace in given communities. Contacts and influences through inter-ethnic communication also enhance relationships and harmonious co-existence. Somehow, linguistic borrowing can take place even in the midst of growing hostility between different ethnic groups. When a whole language is borrowed, frontiers or borders are opened; it goes a long way to enhance understanding and cement relationships, hence, fostering national integration.

However, given the critical role language plays in the life of a people, it becomes imperative to accord it all the attention it deserves in communicating ideas, especially in a multi-ethnic nation like Nigeria. The indigenous language, which is one of the most basic and veritable media of communication, is a vehicle that drives culture. A people's culture is inseparable from their indigenous language because it is vital in explaining their norms and values, thus aiding in the social, economic and technological advancement of the given society. It also binds the people together in unity, builds relationships, and leads to the sustainable growth and development of the society generally.

As it were, just as architecture is the art form that arises out of the human ability to create buildings, literature is the art form that arises out of the human ability to create language. However, the most recent amendment to what constitutes literature is the inclusion of oral narratives or what has been simply called, oral literature (orature). Nigeria, and indeed, Africa is blessed with innumerable sources of oral narratives, probably because of the high level of illiteracy. In other words, what constitutes literature was first unwritten before being documented in written form. But then, this inclusion has not been without serious debate. The argument was that the written word lends itself more easily to analysis, and on the other hand, oral narratives are a legitimate part of a culture's literary capital.

Yemi Ogunbiyi argues that the root of the Nigerian theatre tradition must be sought in the numerous religious rituals and festivals that exist in many Nigerian communities ${ }^{[3]}$. Consequently, it could be argued that the robust literary convention in Nigeria could be traceable to the diverse cultural backgrounds under which the writers have conceptualised their works. This stems from the fact that, as noted earlier, literature mirrors society with the major aim of raising the consciousness of the reader/audience towards the message(s) communicated. Thus, the role of literature in promoting peaceful co-existence in a country and thus achieve national unity cannot be over-emphasised. This explains why Nkem Okoh avers that sensitising every ethnic nationality to its mutual cultural affinity 
with others, irrespective of their language, region, or religion is very critical in national development in that, "A sense of a shared cultural background can unite the citizens and build pride in the nation" ${ }^{(8)}$. He further posits that, "the chief weapon to fight against national disunity and instability is to embark on the massive education of Nigerians, regarding the similarities which we share as a people" (8).

Nigerian literature in English has witnessed an impressive development in the past decade and a half. It manifests the struggles of a people in transition from colonial through independence to a democratic nation. After the protracted fratricidal civil war (1967-70), followed by an oil boom that has turned to "oil doom," creating social and political dislocations that the nation has yet to overcome, it was inevitable that Nigerian literary artists would take up the gauntlet. They have made Nigerian literature, in its many forms, a social act against the wantonness of the new society (Folorunso 1).

As Jean-Paul Sartre puts it, "the arts of a period mutually influence each other and are conditioned by the same social factors." Thus, to Evelyn Nwachukwu Urama, literature is the ultimate vehicle for rebranding the image of any given country. This is through looking at the various ills bedevilling the country and proffering possible solutions. There is no gainsaying the fact that it is a veritable way of pointing the way forward to the citizenry. In doing this, the literary artist goes through an identification process before proffering probable answers to the multifarious social challenges.

Interestingly, indigenous literature in Nigeria has continued to thrive with relative success, especially in Hausa, Yoruba and Igbo languages. It could be said that the Igbo literature gained maturity beginning from leading novelist, Uchenna Tony Ubesie, in his works such as, Ukwa Ruo Oge Ya Odaa, Isi Akwu Dara Nala, Ukpana Okpoko Gbuuru and Juo Obinna. It could then be posited that the development of the Onitsha Market Literature can be hinged on this. Also, literature in Hausa has continued to flourish, as it were, aiding the proliferation of the popular Kano Market Literature. Similarly, the maturity of Yoruba literature dates back to the first three decades of the 20th century and it has continued to take a pride of place in Nigerian indigenous literature (Sumaila, "History of Nigerian Literature").

However, Austin Nwagbara argues that the controversy over the communicative and expressive identity of Nigerian literary in English has taken different dimensions. He states that the views of scholars on the phenomenon can be classified into two schools of thought. First, giving the matter a dualist classification is the perspective of cultural nationalism canvassed by scholars like Obi Wali, Chinweizu et al, Olapade Ajeigbe and Niyi Osundare; and the functionalist perspective is advocated by writer like Chinua Achebe and Gabriel Okara, among others.

The second school of thought believes that the matter could be classified into three categories: Firstly, the accommodationists championed by Chinua Achebe, who presents classic and eloquent defence for the sustenance of the English language; secondly, the gradualists that take a middle ground, arguing in favour of the simultaneous retention of English and the indigenous languages, believing that the language situation would resolve itself over time in a gradual process; and thirdly, the radicalists who engage in unequivocal advocacy for writing in the indigenous languages. Their argument is that any written work, which is conceptualised against a cultural milieu, loses its original flavour once it is translated from the indigenous language to English. Writers like D.O. Fagunwa, Akinwumi Ishola and Adebayo Faletti fall into this category because they ventured into creative writing in the Yoruba language.

Nonetheless, one can also say that Nigeria has been blessed with creative writers, who have demonstrated not just very commendable talents, but also commensurate commitment and patriotism in making their art relevant to their immediate society by way of identifying and capturing its experiences and the generality of its social flux. Although Nigerians have done considerable amount of writing, which can also be categorized under literature before independence, serious written literature is relatively new as it had to wait for Nigerians to master the art of writing, particularly in the foreign language. This is not to infer that before then, there were no forms of existing literature. Rather than utilize the written medium, writers used the spoken language to creatively capture the ways of life, emotions, aspirations, manners and hopes of Nigerians, emphasizing performance and the communal nature of the people (Onukaogu \& Onyerionwu 58-69).

At this juncture, let us go into specifics. It will be necessary for us to take a brief look at the three major genres of literature: poetry, novel and drama, as they have developed over the years in Nigeria. Incidentally, while one can modestly claim to be a playwright, having published a few plays and 
written several others yet to be published, and being acknowledged by scholars as belonging to the third generation of Nigerian playwrights, one cannot say the same thing regarding the poetry and novel genres. But then, the developments in those genres are in the public domain for all to see.

\section{The PoETry GenRe in Nigerian Literature}

Poetry is an art form in which human language is used for its aesthetic qualities. It consists largely of oral or literary works in which language is used in a manner that is felt by its user and audience distinct from ordinary prose. It is a work in which the expression of feelings and ideas is given intensity by the use of distinctive style and rhythm. Thus, a poem is literature that evokes concentrated imaginative awareness of experience or specific emotional response through language chosen and arranged for its meaning, sound, and rhythm.

Poetry is a popular genre that many literary artists delve into. This, probably, is from the understanding that there is no single way in which one can portray one's emotions. It may use condensed or compressed form to convey emotions or ideas to the mind or ear of the reader or listener. It may also use devices such as assonance and repetition to achieve musical or incantatory effects, as exemplified in the oriki or praise-songs among the Yoruba. Very often, poems rely on imagery, word association, and the musical qualities of the language used for their effect. The interactive layering of all these effects to generate meaning is what marks out good poetry.

The foregoing explains why Egya Sule observes that, "poetry has to strip itself of metaphor in order to gain currency," because the reader will not have "the patience to unravel imagery, especially when it tends to be far-fetched" (Akubuiro, "NLNG Prize has not helped"). He points out that while the West prescribes that the African should "write poetry that is universal, that must be understood by all, the west itself hardly produces poetry that is universal." He goes further to aver that,

while the west will insist on an African author explaining in glossary the African concepts he (she) has used, the western author does not care to reciprocate that gesture by explaining in glossary the western concepts he (she) has used (Akubuiro, "NLNG Prize has not helped").

There is no arguing the fact that Nigeria has produced many accomplished poets, beginning from Christopher Okigbo, Gabriel Okara, John Pepper Clark-Bekederemo, Wole Soyinka, Dennis Osadebay, Mamman Jiya Vatsa, Ken Saro-Wiwa, Tanure Ojaide, Niyi Osundare, Okinba Launko (Femi Osofisan), Nduka Otiono, Harry Garuba, Nnimmo Bassey, Ezenwa Ohaeto, Ebinyo Ogbowei, Akachi-Adimora-Ezeigbo, and Onookome Okome. Other versatile poets include, Joe Ushie, Ogaga Ifowodo, Olu Oguibe, Sam Omatseye, Remi Raji, Philip Begho, Uche Nduka, Sadiq Dzukogi, and Arnold Udoka, to mention just a few. Just this recently, Ikeogu Oke won the 2017 NLNG Prize for Literature (Poetry) with his collection, Heresiad.

\section{The Novel GenRe in Nigerian Literature}

The novel has come to attain a high level of prominence in modern national literary cultures around the world. It is almost always considered the most accurate and significant indicator and measure of development in any national literature and beyond. For Nigeria, the novel occupies an enviable status today not just within the country but also in the world literature. Since the novel genre made its debut in the global literary scene, it has always been viewed as the most intensive and demanding task for literary craftsmanship, as the novelist is constantly confronted with the strenuous task of producing an extended work of art and at the same time ensuring the presence of sound logic, compactness and general organization of the many literary elements he/she had deployed and incorporated.

While no other form of literature comprehensively captures the experience of people, in all their socio-political, historical, economic and cultural ramifications, as the novel, it also affords the writer space thereby giving him/her certain level of liberty, essential skill and craft to display (Onukaogu \& Onyerionwu 108). Egya Sule's position encapsulates this scenario succinctly, thus:

The white people or those living in the west are very eager to know what is happening in the jungle called Africa, and the novel has the latitude and amplitude to present what they want to know. ...the reception of Nigerian writing in the west should not form the yardstick for measuring the strength of our writing. That the west promotes a novel or a novelist does not mean it is a 
great work. It only means the novel or the novelist has succeeded in being the best window through which the west can glimpse at Africa (Akubuiro, "NLNG Prize has not...." Emphasis mine).

Incidentally, Nigerians have made quite an impact through this literary genre. Chinua Achebe's Things Fall Apart has become a reference point in world literature, just as 50 years of his second masterpiece, Arrow of God, is currently being celebrated around the world. Egya Sule's observation that, "the novel or the novelist has succeeded in being the best window through which the west can glimpse at Africa," cannot be more apt. Modern Nigerian novelists, the likes of Chimamanda Adichie, Helon Habila, Kaine Agari, Dele Momodu, Adaobi Tricia Nwaubani, Vincent Egbuson, Wale Okediran, Abubakar Gimba, Sam Omatseye, and Yahaya Dangana, among others, have grown to be some of the foremost novelists in the country. Some of them have shown enough evidence of their capability to not just approximate the accomplishment of their predecessors, like Chinua Achebe, Wole Soyinka, Cyprian Ekwensi, T.M. Aluko, Gabriel Okara, Chukwuemka Ike, Buchi Emecheta, Elechi Amadi, John Munonye, Festus Iyayi, Chinweizu, Ken-Saro-Wiwa, Isidore Okpewho, Ben Okri, Mabel Segun, Flora Nwapa, Kole Omotosho, Akachi Adimora-Ezeigbo, and Zaynab Alkali, among others, but to surpass them as they can be sure of leaving the stage for an equally gifted and dedicated group of younger writers, who have all it takes to extend the frontiers of the Nigerian novel. For instance, Chimamanda Adichie has become a global phenomenon with her novels, Purple Hibiscus, Half of a Yellow Sun, and Americanah. Her first novel, Purple Hibiscus, released in October 2003, received wide critical acclaim. It was shortlisted for the Orange Fiction Prize in 2004 and was awarded the Commonwealth Writers' Prize for Best First Book in 2005. Her second novel, Half of a Yellow Sun, published in 2006, has also earned her several prestigious literary awards, among which is the Orange Broadband Prize for Fiction in 2007.

Perhaps, it is worth noting here that, one of the earliest African novelists, Olaudah Equiano (c. 1745 31 Mar. 1797), also known as Gustavus Vassa, a slave who successfully purchased his freedom and was involved in the British movement for the abolition of the slave trade, hailed from the southeastern part of Nigeria. His autobiography, The Interesting Narrative of the Life of Olaudah Equiano, depicts the horrors of slavery and influenced the enactment of the Slave Trade Act of 1807.

\section{THE DRAMA GENRE IN NigERIAN LiTERATURE}

The drama genre in Nigeria, unlike other major genres of literature that have produced writers of national and international acclaim, has not been able to produce literary giants in the mould of Wole Soyinka (Kongi's Harvest), J. P. Clark (The Ozidi Saga), Ola Rotimi (The Gods are not to Blame) and Femi Osofisan (Morountodun) in recent years. The vibrant promises in the poetry and novel genres contrast sharply with the uneventful development of the drama genre. What can one say are the factors responsible for this phenomenon? Apparently, the poor state of live theatre practice is one factor, a subject we have examined elsewhere (Ayakoroma, "Theatre Practice in Nigeria"). Onukaogu and Onyerionwu say this much when they cite Nduka Otiono as stating that Nigerian drama appears to be losing the hard reputation of talents after the likes of Soyinka, Clark, Rotimi and Osofisan (170). It will be recalled that Soyinka brought glory to Nigeria, and indeed the African continent, when he won the Nobel Prize for Literature in 1986. But then, after Soyinka, who next? Every permutation that Chinua Achebe was very well positioned as the next Nigerian to win the Nobel Prize for Literature ended in futility, as the prize eluded him until his eventual demise.

Modern Nigerian drama has not been friendly considering its strategic position as the most social, direct and accessible form of literature, in terms of impact, urgency and immediacy of audience participation, and mass action or response. As noted above, the decline in live theatre culture in Nigeria contributed immensely to drama's infamous decline in the country in recent years in the sense that lack of theatre consciousness has thrown Nigerians into a world of ignorance concerning developments in the dramatic arena. Ahmed Yerima goes further to add that,

the challenge of the home movie, the relative safety of watching the movie at home, and then the lack of security all over the country, in terms of leaving home at certain periods of the day and getting back home safely have all contributed to the challenge (Onukaogu \& Onyerionwu 172).

From the first generation playwrights, Wole Soyinka (Dance of the Forest), Ola Rotimi (Kurunmi), Zulu Sofola (Wedlock of the Gods), J.P. Clark-Bekederemo (Song of a Goat), Wale Ogunyemi (Kiriji 
War), and unsung ones like James Ene Henshaw (This is our Chance), we have the second generation playwrights like Femi Osofisan, Olu Obafemi, Bode Sowande, Ken-Saro-Wiwa, Emeka Nwabueze, Yemi Ajibade, Esiaba Irobi, Tess Onwueme, Stella Oyedepo, Rasheed Gbadamosi, Sam Ukala, Comish Ekiye, and Femi Euba, among others. The third generation has the prolific Ahmed Yerima, Effiong Johnson, Barclays Ayakoroma, Julie Okoh, Saviour Agoro, Austine Anigala, Arnold Udoka, Adinoyi-Ojo Onukaba, Ojo Rasaki Bakare, and Chinyere Okafor, among others. Presently, we have the new-breeds, who, like the under-40s that bestride the Nigerian political landscape, are attempting to leave indelible footprints in the sands of time in the corpus of the country's dramaturgy. Specifically, Alex Asigbo, Tracie Chima Utoh-Ezeajugh, Sunny Ododo, Ben Binebai, Osita Ezenwanebe, Seyi Adigun, Greg Mbajiorgu, and Isiaka Aliagan, to mention a few, exemplify this crop of the vibrant fourth generation playwrights likely to change the face of dramaturgy in Nigeria.

\section{THE IMPACT OF THE DEVELOPMENT OF DRAMA ON THE NigERIAN FILM INDUSTRY}

The drama genre has had determinate impact on the development of the Nigerian film industry, popularly called, Nollywood. Put simply, the exploits of practitioners in Nollywood reflect the circumstances surrounding the advent of television drama in Nigeria. For instance, the first television drama script on WNTV, Ibadan, My Father's Burden, which was produced by Segun Olusola on 6 August, 1961, was written by Wole Soyinka (Ayakoroma, "Trends," 47). Furthermore, the state of the dramatic conventions in various parts of the country reflects in the types of films produced in that zone. For instance, the Hausa films reflect the literary convention there; just as the Yoruba films are yet to free themselves from the apron-strings of the Yoruba popular travelling theatre tradition; and the Igbo language films and even films in English with Igbo settings are projections of Igbo oral narratives and worldview. Generally speaking, the scripts being produced in Nollywood reflect the literary conventions and directions at any given time. The implication here is that as the standard of scripts improves, the quality and content of the films produced in the industry will also improve.

\section{BETWEEN BOOK FESTIVALS AND THE WORLD BOOK CAPITAL 2014}

At this juncture, let us look at the invaluable role of Book Festivals in extending the frontiers of literature. This is pertinent as we are in an International Publishing and Book Fair, here in Casablanca, Morocco. In doing this, we are going to make reference to The Lagos Book and Art Festival (LABAF), Nigeria International Book Fair (NIBF), and the Port Harcourt Book Festival.

The Lagos Book and Art Festival (LABAF) is organised by the Committee for Relevant Art (CORA), led by Jahman Anikulapo, immediate past Editor of The Guardian on Sunday. Basically, it takes place in the second week of November every year; and 15 editions have been held successfully, so far. Dubbed, "Africa's biggest Culture Picnic," LABAF is an international art festival with heavy book content, which reflects the commitment of CORA to develop the minds of the teeming population of Nigeria. Participants are drawn from scholars, writers, artists and journalists from all over the world. The organizers say of the festival thus:

The Lagos Book and Art Festival is an advocacy idea; we are promoting the idea of people reading books; gaining knowledge, freeing themselves from ignorance. There are reading workshops for teenagers; panel discussions on contents of selected books; cross cultural exchange between Nigerian writers and writers from elsewhere in the world...

(http://www.lagosbookartfest.org/about-labaf.html).

LABAF has become a landmark event in the nation's culture calendar with sprawling book displays, exhibitions, live music and drama performances, and dedicated literary events that examine the content of books. Toyin Akinosho, an arts critic, who organises the event with Jahman Anikulapo, states:

We don't just put together a book fair, a performance concert, a literary festival or an art expo, what we do is a healthy fusion of all four in a festival atmosphere, and for the past 14 years, the festival has become an important destination for families, literary and art enthusiasts, culture producers, children and even lovers. We have had people who came as children years ago still attending now as young adults. We have also had people who met at the festival grounds for the first time years ago, still attending as married couples. 
What keeps them coming back is the way the festival allows them to engage with culture in a fun atmosphere, that is why it is Africa's Biggest Culture Picnic.

Apart from LABAF, The Garden City Literary Festival, which started in 2008, has become another veritable platform that has moved the literary works of Nigerians across borders. The festival has since been reinvented as, The Port Harcourt Book Festival, according to Mrs. Koko Kalango, founder of Rainbow Book Club (RBC), organisers of the event for the Rivers State Government. The rebranding was part of efforts to institutionalise the festival and make it outlive the administration of Governor Chibuike Rotimi Amaechi that conceived it. According to Kalango, the name change was in line with international best practices as similar events like the London Book Fair and the Cape Town Book Festival, amongst others, were named after their host cities, and that Port Harcourt's designation as UNESCO World Book Capital 2014 had generated a lot of interest in the city as a literary hub. It is believed that the change from Garden City Literary Festival to Port Harcourt Book Festival will help consolidate the city's reputation as a haven for literary activities.

The United Nations Educational, Scientific and Cultural Organisation (UNESCO) named the city of Port Harcourt, Rivers State, Nigeria, the World Book Capital for the year 2014. The initiative, in addition to the celebration of World Book and Copyright Day, represents a collaborative undertaking by key stakeholders in the publishing world and cities to promote books and literacy. The Selection Committee chose Port Harcourt on account of the quality of its programme, its focus on youth and the impact it will have on improving Nigeria's book culture, reading culture, as well as writing and publishing to improve literacy rates. Port Harcourt is the 14th city to be designated World Book Capital following Madrid (2001), Alexandria (2002), New Delhi (2003), Antwerp (2004), Montreal (2005), Turin (2006), Bogota (2007), Amsterdam (2008), Beirut (2009), Ljubljana (2010), Buenos Aires (2011), Yerevan (2012) and Bangkok (2013) (http://www.unesco.org/new/en/media-services).

The Nigeria International Book Fair (NIBF), coming up in the second week of May every year, is a third window for exhibition of literary works that has been very consistent. It is an annual book trade and exhibition that creates an effective platform for stakeholders in the book industry both within and outside Nigeria to network and have business interface for the growth of their respective businesses. The $13^{\text {th }}$ edition of the fair is scheduled to hold from 5-10 May, 2014 at the Multi-purpose Hall, University of Lagos, Akoka-Lagos, Nigeria.

NIBF is the flagship of the events organized by the Nigerian Book Fair Trust (NBFT), which was incorporated in 1998 and enjoys the endorsement of the Federal Government of Nigeria and the Tertiary Education Trust Fund (TETFUND). NBFT is a coalition of the major stakeholders in the Nigerian Book Sector, comprising the Nigerian Publishers Association, Nigerian Book Foundation, Booksellers Association of Nigeria, Association of Nigerian Printers, Nigerian Library Association, Association of Nigerian Authors and the Association of Non-Fiction and Academic Authors of Nigeria. NBFT, apart from the annual Nigeria International Book Fair, also organizes National Book Fairs in Abuja, Enugu and Ibadan.

\section{The Contribution of Literary PrizeS}

Nigerian writers, both at home and abroad, have been winning prizes even against some of the best in Africa and the world at large. Apart from Soyinka winning the Nobel Prize for Literature, Nigerians are among those who have won the Booker Prize, the Caine Prize, the Commonwealth Poetry Prize, the Fonlon/Nichols Award, the Pulitzer Prize, the Man Booker Prize, the Noma Awards, the Orange Prize, and the Wole Soyinka Prize, to mention a few. Some of the exploits of Chimamanda Adichie, for instance, have been mentioned earlier. However, this has continued to be at the detriment of writing in Nigerian indigenous languages as emerging writers are not interested in writing in the indigenous languages because of the limited reach and acceptability. It has dampened the interest of both the old and younger writers in spite of the obviously important role of language in defining the identity of a people. This is compounded by the fact that there are no conscious efforts at promoting the art of indigenous literature as publishers hardly engage indigenous language writers, giving limited reach and marketing considerations as reasons for the lack of interest (Adesowo, "Promoting Writing...").

However, the Nigeria Prize for Literature was established in 2005 by the Nigeria Liquefied Natural Gas Ltd (NLNG) with the aim of identifying excellent literature and rewarding such. Put succinctly, 
its overall objective is, "to encourage and stimulate authorship and the development of Nigeria literary culture in terms of creative writing, production and reading and in the process guide literary taste" (Akubuiro, "NLNG Prize"). It started by alternating the prizes annually: Poetry, Drama and Prose, respectively; but it has since added Children's Literature as a fourth genre. For instance, the prize for 2014 is based on drama. That the NLNG Prize has become the Nobel equivalent in Nigeria is not an over-statement. This is so much so that Dr. Gabriel Okara, joint winner (with Ezenwa Ohaeto) in the maiden edition in 2005, commented on its significance, thus:

I consider it more valuable than the Commonwealth Prize I won back in 1979.

Winning the NLNG Prize means I have been recognized in my home base. It is important to me and has given me confidence in my own base about my writing (Akubuiro, "NLNG Prize").

Unfortunately, no NLNG Prizes were awarded in 2005 and 2009 because the Literature Committee did not find any of the shortlisted entries worthy of the Award. Thus, while Gabriel Okara commends the institution of the NLNG Prize, Egya Sule thinks otherwise. To him, the prize has not helped in the development of Nigerian Literature. He premises his argument on the need to put in place, "a holistic approach that takes into consideration all aspects of literary production such as a good reading culture, workshop on creative writing, editing and publishing outfit, and writing residency" (Akubuiro, "NLNG Prize..."). Sule is of the opinion that, "Achebe's oeuvre is that it adequately responds to the cultural needs of its time. Achebe is a great writer because he wrote Things Fall Apart at the time he wrote it" (Akubuiro, "NLNG Prize...").

As a point of fact, there is no doubt that the NLNG Prize for Literature has come a long way. As Managing Director of Nigeria Liquefied Natural Gas Limited (NLNG), Mr. Chima Ibeneche stated, the Nigeria Prize for Literature and the Nigeria Prize for Science have become, "the pedestal for people of ideas" in order to celebrate them, thereby creating international prizes of repute with the support of all Nigerians and the two prizes have gone beyond being described as products of good intentions; rather, they have become "landmarks" ("NLNG Aimed").

As for the Caine Prize for African Writing, described as Africa's leading literary award, E.C. Osondu won the 2009 edition with "Waiting." Rotimi Babatunde won the 2012 edition, for his short story, entitled, "Bombay's Republic;" while Tope Folarin won the 2013 Prize, for his short story entitled, "Miracle." In fact, analysts laud the dominant status of Nigerian writers in winning the Caine Prize for African Writing five times already in its 14 editions.

\section{CONCLUSION}

It this paper, it has been noted that languages and national literature are, no doubt, positive characteristics of identity to a people. The authenticity of Nigerian literature can be said to be that which is written in the indigenous languages. Thus, the study of Nigerian literature can only be complete by first examining and appreciating the origin and development of Nigerian literature in the indigenous languages and how they can be invaluable, regarding the territorial identity of the people. Although many writers in Nigeria have attempted to abandon the use of English in favour of indigenous languages in their writings, the fact that literatures in indigenous languages are limited to a handful of indigenous readers has continued to make most of them to revert to writing in English.

Literature has a very critical role in the development of language and culture, which informs why there is need for appreciable volume of written literatures in the indigenous languages. Somehow, the bulk of Nigerian literary writing exist in English, making literary works written in English to be more predominant, enjoying far more wider acceptability and readership thereby consigning indigenous writings to minimal usage as they become visible only in informal and immediate culture-related domains of writing.

In conclusion, we could say that Nigerian literature is still in its transformational state. But then, considering the various platforms we have identified above that have been put in place to encourage literary culture, including the "Bring Back the Book (BBB)" initiative of Dr. Goodluck Ebele Jonathan, former President of the Federal Republic of Nigeria, it could be said that there is a bright future for literary writings in Nigeria. The writings will continue to go beyond the borders of the country, telling the "Nigerian story" and the "Nigerian identity" to the outside world. 


\section{REFERENCES}

[1] “About Lagos Book and Art Festival.” Retrieved 4 Feb. 2014, from: http://www.lagosbookartfest.org/ about-labaf.html

[2] “About Nigeria International Book Fair.” Retrieved 4 Feb. 2014, from: http://www.nibfng.org

[3] Adesowo, Jerry. "Promoting Writing in Indigenous Languages." Sunday Trust, 2 Aug. 2009. Retrieved 5 Feb. 2014, from: <http://sundaytrust.com.ng/index.php/the-arts/5036-promoting-writing-in-indigenouslanguages>

[4] Adewakun, Akin. "Garden City Literary Festival gets make over." Posted Sunday, 11 Aug. 2013. Retrieved 6 Feb. 2014, from: http://www.tribune.com.ng/news2013/index.php/en/component/k2/item/ 18802-garden-city-literary-festival-gets-make-over.html

[5] Akubuiro, Henry. "Nigerian Literature Living on Past Glory - NLNG." Posted Saturday, 29 Jan. 2011. Retrieved 8 Feb. 2014, from: http://www.nigerianbestforum.com/blog/nigerian-literature-living-on-pastglory-\%e2\%80\%93-nlng/\#sthash.3EPZO6DD.dpuf

[6] "NLNG Prize: Adeleke Adeyemi Smiles at Last." Posted Saturday, 15 Oct. 2011. Retrieved 8 Feb. 2014, from: http://www.nigerianbestforum.com/blog/nlng-prize-adeleke-adeyemi-smiles-at-last/\#sthash.UMTM dxua.dpuf

[7] "NLNG Prize has not helped Nigerian Literature." Posted Saturday, 17 Dec. 2011. Retrieved 8 Feb. 2014, from: http://www.nigerianbestforum.com/blog/nlng-prize-has-not-helped-nigerian-literature/\#sthash.Ueiy FNM0.dpuf

[8] Ayakoroma, Barclays F. "Mainstreaming Language and the Arts in the Nigerian Educational System: The Importance of Being Relevant." Keynote Lecture Delivered at the 2012 School of Arts Annual Conference, Alvan Ikoku Federal College of Education, Owerri, Imo State. 7 Nov. 2012.

[9] "Reviving the use of indigenous languages in the contemporary Nigerian society: The National Institute for Cultural Orientation (NICO) initiative." Paper Delivered at the African Theatre Association (AfTA) Annual International Conference at the University of Cape Town, Cape Town, 12-15 July 2012.

[10] "Theatre Practice in Nigeria: To be or not to be." Paper Delivered at the International Theatre Day (ITD) 2012, organised by National Association of Nigerian Theatre Arts Practitioners (NANTAP), at the Cyprian Ekwensi Cultural Centre, Abuja, on Tuesday, 27 Mar. 2012.

[11] "Trends in Contemporary Nigerian Video Film Industry: A Study of Selected Emergent Genres." PhD Dissertation, University of Port Harcourt, Nigeria. 2007.

[12] Betiang, Liwhu. Fundamentals of Dramatic Literature. Calabar: BAAJ International Company \& Atlantic Publishing Company, 2001.

[13] Darah, G. G. (Ed). Radical Essays on Nigerian Literatures. Lagos: Malthouse Press Limited, 2008.

[14] Eagleton, Terry. "Introduction: What is Literature?" Retrieved 1 Feb. 2014, from: http://www.dartmouth. edu/ engl5vr/Eagle1.html

[15] Folorunso, Femi. "Works from a Country in Progress: Nigerian Literature." World Press Review, Jan. 1993. Retrieved 6 Feb. 2014 from: <http://emeagwali.com/nigeria/literature/nigerian-literature-jan93. html>.

[16] How Nigerians Dominate The Caine Prize for African Writing." Retrieved 7 Feb. 2014, from: http://www.lagosbookartfest.org/new/331-how-nigerians-dominate-the-caine-prize-for-africanwriting.html

[17] Ogunbiyi, Yemi. "Nigerian Theatre and Drama: A Critical Profile." In Ogunbiyi, Yemi (Ed.). Drama and Theatre in Nigeria: A Critical Source Book. Lagos: Nigeria Magazine, 1981: 3-53.

[18] Oke, Ikeogu. Heresiad. Ibadan: Kraft Books Ltd, 2017.

[19] Onukaogu, Allwell A. \& Onyerionwu, Ezechi. $21^{\text {st }}$ Century Nigerian Literature: An Introductory Text. Ibadan: Kraft Books Ltd, 2009.

[20] “Port Harcourt named World Book Capital 2014." Retrieved 2 Feb. 2014, from: <http://www.unesco. org/new/en/media-services/singleview/news/port_harcourt_named_world_book_capital_2014/\#.UvyiCvldXqQ>

[21] Sartre, Jean-Paul. What is Literature? Trans. Bernard Frechtman. New York: Philosophical Library, Inc., 1949.

[22] Sumaila, Umaisha. "History of Nigerian Literature." Everything Literature, December, 2010. Retrieved 5 Feb. 2014, from: <http://everythinliterature.blogspot.com/2010/12/ history-of-nigerian-literature.html> 
[23] Urama, Evelyn N. "Literature: The Ultimate Vehicle for National Image Re-Branding.” In Ododo, Sunday \& Bodunde, Charles (Eds.). ObafConfab: Book of Proceedings. Abuja: National Commission for Museums and Monuments, 2010: 423-432.

[24] "What is Literature." Retrieved 1 Feb. 2014, from: <http://dlibrary.acu.edu.au/staffhome /siryan/academy/foundation/what_is_literature.html>

Citation: Barclays Foubiri Ayakoroma. Nigerian Literature: Beyond Languages and Borders. International Journal on Studies in English Language and Literature (IJSELL), vol 5, no. 10, 2017, pp. 74-83. doi:http://dx.doi.org/10.20431/2347-3134.0510010.

Copyright: (c) 2017 Authors. This is an open-access article distributed under the terms of the Creative Commons Attribution License, which permits unrestricted use, distribution, and reproduction in any medium, provided the original author and source are credited. 